\title{
Infections, NCDS, and the scourge of cyclones and Ebola in sub-Saharan Africa
}

\author{
James K Tumwine
}

African Health Sciences.

DOI: https://dx.doi.org/10.4314/ahs.v19i1.1

Cite as: Tumwine JK. Infections, NCDS, and the scourge of cyclones and Ebola in sub-Saharan Africa. Afri Health Sci. 2019;19(1): i-iv. https:/ / dx.doi.org/10.4314/ahs.v19i1.1

Welcome to this March 2019 issue of African Health Sciences. It comes at a time when our continent has been hit by a major cyclone along the south east coast, affecting largely Mozambique, Malawi and Zimbabwe. ${ }^{1}$

Meanwhile we continue struggling with a huge burden of endemic infectious diseases with worrying non- communicable diseases, especially cancer and diabetes mellitus. Thus, we have papers on TB susceptibility ${ }^{2}$, sputum collection for TB diagnosis in Burkina $\mathrm{Faso}^{3}$, and a review of long neglected diseases such as leishmaniasis ${ }^{4}$, schistosomiasis $^{5}$ and Hymenolesis nana ${ }^{6}$. While Ugandan authors ${ }^{7}$ bring us to speed on bednets, a Tunisian group, have an interesting treatise on resistance to temephos ${ }^{8}$ and organophosphate ${ }^{9}$ by Culex pipiens pipiens mosquitoes. The infectious disease theme continues with three papers ${ }^{10,11,12}$ on Staphylococus aureus. This is followed by very interesting work on various viral illnesses ${ }^{13,14,15,16}$, and disinfection ${ }^{17}$. An exploration on immuno deficiencies then follows ${ }^{18,19}$. This leads into sexual and reproductive health issues. Specifically, there is a report on high risk sexual behaviors among adolescents in Nigeria ${ }^{20}$, and sexual harassment in higher education institutions in South Africa ${ }^{21}$. This is followed by issues of gender based violence in Nigeria and Mozambique ${ }^{22,23}$.

The theme then thrusts us into the issue of risk factors for still births in Pakistan ${ }^{24}$, prevention of postpartum haemorrhage ${ }^{25}$, and UTIs in pregnancy ${ }^{26}$, universal health ac$\operatorname{cess}^{27}$, and feticide ${ }^{28}$. Newborn survival ${ }^{29}$, resuscitation ${ }^{30}$, malnutrition ${ }^{31}$, child health services in $\mathrm{Uganda}^{32}$, and vaccination coverage ${ }^{33}$ cap this section on child health.

Now to the long awaited but ubiquitous challenge of non-communicable diseases! But you people! What are we going to do? The section includes a randomized clinical trial of fenugreek versus glibenclamide for treatment of diabetes mellitus ${ }^{34}$ and gives us a flavour of indigenous knowledge and herbal medicine. The next five papers all tackle aspects of diabetes mellitus (DM). Hence, we have one paper on the use of neutrophil to lymphocyte ratio for assessing control in type $2 \mathrm{DM}^{35}$, albumin to creatinine ratio for microalbuminuria in $\mathrm{DM}^{36}$, diabetic foot ulcers ${ }^{37}$, use of the insulin pen ${ }^{38}$, and perceived barriers to insulin the therapy in type $2 \mathrm{DM}$ patients ${ }^{39}$.

Now to other non-communicable diseases (NCDs). Anthracyclines and cardiotocity in cancer patients ${ }^{40}$, mitral valve disease ${ }^{41}$, prostate specific antigen ${ }^{42}$, DNA in Barrett's esophagus ${ }^{43}$, amelostoma and reactive hyperplasia in Nigeria ${ }^{44,45}$ and precancerous lesions and HIV in Ethio$\mathrm{pia}^{46}$ all usher in diverse but disturbing cancers.

The next papers are on aspects of practice of surgery, psychiatry and medicine in Africa. Strange bed fellows? Hence, we have a paper on the use of the laryngeal mask on post-operative sore throat ${ }^{47}$, vortioxetin for depres$\operatorname{sion}^{48}$, orthopedic back pain and depression ${ }^{49}$, propofol for emergency tonsillectomy ${ }^{50}$, elective abdominal surgery complications ${ }^{51}$, hypertensive crises $^{52}$, surgical emergencies $^{53}$, surgical needs of the elderly ${ }^{54}$, and prophylactic removal of the third molar ${ }^{55}$.

We conclude this rich menu of papers with what one would call a mixed salad: effect of oral contraceptives on periodontal health ${ }^{56}$; mental health and temporomandibular disorders ${ }^{57}$; and end with the reliability and validity of the patient activation measure $\mathrm{PAM}^{58}$.

\section{References}

1. OHCA. Tropical Cyclone Idai -Mar 2019 Relief Web. 2019.

2. Zhen L-B, Sun Y-P, Chen Y-Y, Yin L-S. IL-18 polymorphisms and tuberculosis susceptibility: a meta-analysis. Afri Health Sci. 2019;19(1): 1311-1320. https://dx.doi. org/10.4314/ahs.v19i1.2

3. Kabore A, Tranchot-Diallo J, Sanou A, Hien H, Daneau G, Gomgnimbou MK, Meda N, Sangaré L. Why Oral antiseptic mouth rins- ing before sputum collection

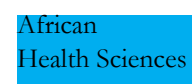

(C) 2019 Tumwine JK. Licensee African Health Sciences. This is an License (https://creativecommons.org/licenses/BY/4.0), which permits unrestricted use, distribution, and reproduction in any medium, provided the original work is properly cited. 
cannot reduce contamination rate of mycobacterial culture in Burkina-Faso. Afri Health Sci. 2019;19(1): 13211328. https://dx.doi.org/10.4314/ahs.v19i1.3

4. Tabbabi A. Review of Leishmaniasis in the Middle East and North Africa. Afri Health Sci. 2019;19(1): 13291337. https://dx.doi. org/10.4314/ahs.v19i1.4

5. Otuneme OG, Obebe OO, Sajobi TT, Akinleye WA, Faloye TG. Prevalence of Schistosomiasis in a neglected community, South western Nigeria at two points in time, spaced three years apart. Afri Health Sci. 2019;19(1): 13381345. https://dx.doi.org/10.4314/ahs.v19i1.5

6. Shahnazi M, Mehrizi MZ, Alizadeh SA, Heydarian P, Saraei M, Alipour M, Hajialilo E. Molecular characterization of Hymenolepis nana (Cestoda: Cyclophyllidea: Hymenolepididae) based on nuclear rDNA ITS2 gene marker. Afri Health Sci. 2019;19(1): 1346- 1352. https:// dx.doi.org/10.4314/ahs.v19i1.6

7. Andinda M, Mulogo E, Turyakira E, Batwala V. Predictors of sleeping under cost-free mosquito bed nets among children under-five years in Mbarara, Uganda: a household survey. Afri Health Sci. 2019;19(1): 1353-1360. https://dx.doi.org/10.4314/ahs.v19i1.7

8. Tabbabi A, Daaboub J, Laamari A, Cheikh RB, Feriani M, Boubaker C, Jha IB, Cheikh HB. Evaluation of resistance to temephos insecticide in Culex pipiens pipiens (Diptera: Culicidae) larvae collected from three districts of Tunisia. Afri Health Sci. 2019;19(1): 1361-1367. https://dx.doi.org/10.4314/ahs.v19i1.8

9. Tabbabi A, Daaboub J, Cheikh RB, Laamari A, Feriani M, Boubaker C, Jha IB, Cheikh HB. The potential role of urbanization in the resistance to organophosphate insecticide in Culex pipiens pipiens from Tunisia. Afri Health Sci. 2019;19(1): 1368- 1375. https://dx.doi.org/10.4314/ahs. v19i1.9

10. HA, Elsherbini AM, MA S. Glyceryl trinitrate blocks staphyloxanthin and biofilm formation in Staphylococcus aureus. Afri Health Sci. 2019;19(1). 1376-1384. https://dx.doi.org/10.4314/ahs.v19i1.10

11. Adesoji AT, Onuh JP, Bagu J, SA I. Prevalence and antibiogram study of Staphylococcus aureus isolated from clinical and selected drinking water of Dutsin-Ma, Katsina state, Nigeria. Afri Health Sci. 2019;19(1). 1385-1392. https://dx.doi.org/10.4314/ahs.v19i1.11

12. Latha T, Anil B, Manjunatha $H$, Chiranjay M, Elsa D, Baby N, et al. MRSA: the leading pathogen of orthopedic infection in a tertiary care hospital, South India. Afri Health Sci. 2019;19(1). 1393-1401. https://dx.doi. org/10.4314/ahs.v19i1.12

13. Wang H, Chen L, Luo J, H H. NP and NS1 proteins of H5N1 virus significantly upregulated IFITM1, IFITM2, and IFITM3 in A549 cells. Afri Health Sci. 2019;19(1). 1402-1410. https://dx.doi.org/10.4314/ahs.v19i1.13

14. Helal T El A, Radwan NA, Mahmoud HA, Zaki AME, Ahmed NS, Wahib AAA, et al. The role of hepatic progenitor cells in predicting response to therapy in Egyptian patients with chronic hepatitis C, genotype 4. Afri Health Sci. 2019;19(1). 1411-1421. https://dx.doi. org/10.4314/ ahs.v19i1.14

15. Burman C, M A. Improved adherence to anti-retroviral therapy among traditionalists: reflections from rural South Africa. Afri Health Sci. 2019;19(1). 1422-1432. https://dx.doi. org/10.4314/ahs.v19i1.15

16. Gozdas HT. Evaluation of Crimean-Congo hemorrhagic fever suspected cases admitted to a secondary care hospital in Kastamonu, Turkey between 2014-2017. Afri Health Sci. 2019;19(1). 1433-1440. https://dx.doi. org/10.4314/ahs.v19i1.16

17. Huang Q, Luo A, Jiang L, Zhou Y, Yang Y, Liu Q, et al. Disinfection efficacy of green synthesized gold nanoparticles for medical disin- fection applications. Afri Health Sci. 2019;19(1). 1441-1458. https://dx.doi. org/10.4314/ ahs.v19i1.17

18. Galal N, Ohida M, Meshaal S, Abd Elaziz D, I E. Targeted screening for primary immunodeficiency disorders in the neonatal period and early infancy. Afri Health Sci. 2019;19(1). 1449-1459. https://dx.doi. org/10.4314/ahs. v19i1.18

19. Zahid S, Mustafa A, Dina A, Sawsan B, Felwa A, Mohammed $G$, et al. Nickel challenge up regulates CD69 expression on $\mathrm{T}$ lympho- cyte sub-sets from patients with nickel induced contact dermatitis. Afri Health Sci. 2019;19(1). 1460-1466. https://dx.doi. org/10.4314/ahs. v19i1.19

20. Odeigah L, Rasaki SO, Ajibola AF, Hafsat AA, Sule AG, Musah Y. High risk sexual behavior among adolescent senior secondary school students in Nigeria. Afri Health Sci. 2019;19(1). 1467-1477. https://dx.doi. org/10.4314/ ahs. v19i1.20

21. Oni HT, Tshitangano TG, Akinsola HA. Sexual harassment and victimization of students: a case study of a higher education institution in South Africa. Afri Health Sci. 2019;19(1). 1478-1485. https:// dx.doi. org/10.4314/ ahs. v19i1.21

22. Fawole OI, M. van Wyk J, Balogun BO, Akinsola OJ, 
A A. Preparing medical students to recognize and respond to gender based violence in Nigeria. Afri Health Sci. 2019;19(1). 1486-1498. https:// dx.doi. org/10.4314/ ahs. v19i1.22

23. Cebola BR, Menegazzo F, Salmaso L, Facchin P, Isidoris V, Figueredo RL, et al. Pattern of domestic violence from 2011 to 2015 in Beira, Mozambique. Afri Health Sci. 2019;19(1). 1499-1506. https://dx.doi.org/10.4314/ahs. v19i1.23

24. Afshan K, Narjis G, M Q. Risk factors and causes of stillbirths among pregnant women in Pakistan. Afri Health Sci. 2019;19(1). 1507-1516. https://dx.doi.org/10.4314/ ahs.v19i1.24

25. Muhammad R, Isah A, Agida T, Akaba G. A prospective study to compare the effectiveness of adjunctive rectal misoprostol or oxytocin titration in the prevention of primary post-partum haemorrhage in at risk patients. Afri Health Sci. 2019;19(1). 1517-1524. https://dx.doi. org/10.4314/ahs.v19i1.25

26. Ndamason LM, Marbou WJT, Kuete V. Urinary tract infections, bacterial resistance and immunological status: a cross sectional study in pregnant and non-pregnant women at Mbouda Ad-Lucem Hospital. Afri Health Sci. 2019;19(1). 1525-1535. https://dx.doi.org/10.4314/ ahs. v19i1.26

27. Benson AE, Benson MJ, Luke AH. Assessment of maternal referral systems used for a rural Zambian hospital: the development of setting specific protocols for the identification of complications. Afri Health Sci. 2019;19(1). 1536-1543. https://dx.doi.org/10.4314/ahs. v19i1.27

28. Ş1k A, Bilecan S, Kumbasar S, Akpak YK, YA A. Does feticide shorten termination duration in second trimester pregnancy termina- tions? Afri Health Sci. 2019;19(1). 1544-1553. https://dx.doi.org/10.4314/ahs.v19i1.28

29. Uleanya ND, Aniwada EC, Ekwochi U, ND U. Short term outcome and predictors of survival among birth asphyxiated babies at a tertiary academic hospital in Enugu, SouthEast, Nigeria. Afri Health Sci. 2019;19(1). 15541562. https://dx.doi.org/10.4314/ahs.v19i1.29

30. Okonkwo IR, Ezeaka VC, Mustapha B, Ezeanosike O, Tongo O, Okolo AA, et al. Newborn resuscitation practices and paucity of resuscitative devices in Nigeria; a call to action. Afri Health Sci. 2019;19(1). 1563-1565. https:// dx.doi.org/10.4314/ahs.v19i1.30

31. Malek A, Hashemi M, Anjomrooz M, Torabi P, B I. Malnutrition and medical nutrition therapy in hospital- ized children: a case study of using national malnutrition screening tools in northeastern Iran. Afri Health Sci. 2019;19(1). 1566-1573. https://dx.doi.org/10.4314/ahs. v19i1.31

32. Muhwezi WW, Palchik EA, Kiwanuka DH, Mpanga F, Mukundane M, Nanungi A, et al. Community participation to improve health services for children: a methodology for a community dialogue intervention in Uganda. Afri Health Sci. 2019;19(1). 1574-1581. https://dx.doi. org/10.4314/ahs.v19i1.32

33. Adebowale A, Obembe T, E B. Relationship between household wealth and childhood immunization in coreNorth Nigeria. Afri Health Sci. 2019;19(1). 1582-1593. https://dx.doi.org/10.4314/ahs.v19i1.33

34. Najdi RA, Hagras MM, Kamel FO, RM M. A randomized controlled clinical trial evaluating the effect of Trigonella foenum-graecum (fenugreek) versus glibenclamide in patients with diabetes. Afri Health Sci. 2019;19(1). 1594-1601. https://dx.doi.org/10.4314/ahs. v19i1.34

35. Duman TT, Aktas G, Atak BM, Kocak MZ, Erkus E, H S. Neutrophil to lymphocyte ratio as an indicative of diabetic control level in type 2 diabetes mellitus. Afri Health Sci. 2019;19(1). 1602-1606. https://dx.doi.org/10.4314/ ahs.v19i1.35

36. Muddu M, Mutebi E, Ssinabulya I, Kizito S, Mulindwa F, CM K. Utility of albumin to creatinine ratio in screening for microalbu- minuria among newly diagnosed diabetic patients in Uganda: a cross sectional study. Afri Health Sci. 2019;19(1). 1607-1616. https://dx.doi. org/10.4314/ahs. v19i1.36

37. Anyim O, Okafor C, Young E, Obumneme-Anyim I, C N. Pattern and microbiological characteristics of diabetic foot ulcers in a Nigerian tertiary hospital. Afri Health Sci. 2019;19(1). 1617-1627. https://dx.doi.org/10.4314/ ahs.v19i1.37

38. Tosun B, Cinar FI, Topcu Z, Masatoglu B, Ozen N, Bagcivan $G$, et al. Do patients with diabetes use the insulin pen properly? Afri Health Sci. 2019;19(1). 1628-1637. https://dx.doi.org/10.4314/ahs.v19i1.38

39. Hussein A, Mostafa A, Areej A, Mona A, Shimaa A, Najd A, et al. The perceived barriers to insulin therapy among type 2 diabetic patients. Afri Health Sci. 2019;19(1). 1638-1646. https://dx.doi.org/10.4314/ahs.v19i1.39 40. Kibudde S, Mondo CK, Kibirige D, Walusansa V, J O. Anthracycline induced cardiotoxicity in adult cancer patients: a prospective co- hort study from a specialized oncology treatment centre in Uganda. Afri Health Sci. 
2019;19(1). 1647-1656. https://dx.doi.org/10.4314/ahs. v19i1.40

41. Guler S, Varol E. The relation between echocardiographic epicardial fat thickness and mitral annular calcification. Afri Health Sci. 2019;19(1). 1657-1664. https:// dx.doi.org/10.4314/ahs. v19i1.41

42. Bello JO, Buhari T, Mohammed TO, Olanipekun $\mathrm{HB}$, Egbuniwe AM, Fasiku OK, et al. Determinants of prostate specific antigen screening test uptake in an urban community in North-Central Nigeria. Afri Health Sci. 2019;19(1). 1665-1670. https://dx.doi.org/10.4314/ ahs. v19i1.42

43. Keles M, Sahin I, Kurt A, Bozoglu C, Simsek G, Kabalar E, et al. Mitochondrial DNA deletions in patients with esophagitis, Barrett's esophagus, esophageal adenocarcinoma and squamous cell carcinoma. Afri Health Sci. 2019;19(1). 1671-1676. https://dx.doi.org/10.4314/ ahs. v19i1.43

44. Adisa AO, Osayomi T, Effiom OA, Kolude B, Lawal AO, Soyele OO, et al. A geographical analysis of ethnic distribution of jaw amelo- blastoma in Nigerians. Afri Health Sci. 2019;19(1). 1677-1686. https://dx.doi. org/10.4314/ ahs. v19i1.44

45. Soyele OO, Ladeji AM, Adebiyi KE, Adesina OM, Aborisade AO, Olatunji AS, et al. Pattern of distribution of reactive localised hyperplasia of the oral cavity in patients at a tertiary health institution in Nigeria. Afri Health Sci. 2019;19(1). 1687-1694. https://dx.doi. org/10.4314/ ahs. v19i1.45

46. Kassa LS, Dile WM, Zenebe GK, AM B. Precancerous lesions of cervix among women infected with HIV in Referral Hospitals of Am- hara Region, Northwest Ethiopia: a cross sectional study. Afri Health Sci. 2019;19(1). 1695-1704. https://dx.doi. org/10.4314/ ahs. v19i1.46 47. Waruingi D, Mung'ayi V, Gisore E, Wanyonyi S. A randomised controlled trial of the effect of laryngeal mask airway manometry on post- operative sore throat in spontaneously breathing adult patients presenting for surgery at a university teaching hospital. Afri Health Sci. 2019;19(1). 1705-1715. https://dx.doi. org/10.4314/ ahs. v19i1.47

48. Zheng J, Wang Z, E L. The efficacy and safety of $10 \mathrm{mg} /$ day vortioxetine compared to placebo for adult major depressive disorder: a me-taanalysis. Afri Health Sci. 2019;19(1). 1716-1726. https://dx.doi. org/10.4314/ ahs. v19i1.48

49. Omoke NI, MN I. Analysis of risk factors for depres- sion among patients with chronic low back pain in orthopaedic clinic of a Nigerian teaching hospital. Afri Health Sci. 2019;19(1). 1727-1735. https://dx.doi. org/10.4314/ ahs. v19i1.49

50. Jalili S, Esmaeeili A, Kamali K, V R. Comparison of effects of propofol and ketofol (Ketamine-Propofol mixture) on emergence agitation in children undergoing tonsillectomy. Afri Health Sci. 2019;19(1). 1736-1744. https:/ / dx.doi. org/10.4314/ ahs. v19i1.50

51. Ufoaroh CU, Ele PU, Anyabolu AE, Enemuo EH, Emegoakor CD, Okoli CC, et al. Pre-operative pulmonary assessment and risk factors for post-operative pulmonary complications in elective abdominal surgery in Nigeria. Afri Health Sci. 2019;19(1). 1745-1756. https:// dx.doi. org/10.4314/ ahs. v19i1.51

52. Nakalema I, Kaddumukasa M, Nakibuuka J, Okello E, Sajatovic M, E K. Prevalence, patterns and factors associated with hypertensive crises in Mulago hospital emergency department; a cross-sectional study. Afri Health Sci. 2019;19(1). 1757-1767. https:// dx.doi. org/10.4314/ ahs. v19i1.52

53. Onyemaechi NOC, Urube SU, SO E. Pattern of surgical emergencies in a Nigerian tertiary hospital. Afri Health Sci. 2019;19(1). 1768-1777. https:// dx.doi. org/10.4314/ ahs. v19i1.53

54. Tran TM, Fuller AT, Butler EK, Muhumuza C, Ssennono VF, Vissoci JR, et al. Surgical need among the ageing population of Uganda. Afri Health Sci. 2019;19(1). 1778-1788. https:// dx.doi. org/10.4314/ ahs. v19i1.54

55. Anyanechi CE, Saheeb BD, UC O. Is prophylactic removal of impacted mandibular third molar justified in all patients? A prospective clinical study of patients 50 years and above. Afri Health Sci. 2019;19(1). 1789-1794. https:// dx.doi. org/10.4314/ ahs. v19i1.55

56. Prachi S, Jitender S, Rahul C, Jitendra K, Priyanka M, S D. Impact of oral contraceptives on periodontal health. Afri Health Sci. 2019;19(1). 1795-1800. https:// dx.doi. org/10.4314/ ahs. v19i1.56

57. Atsü SS, Güner S, Palulu N, Bulut AC, I K. Oral parafunctions, personality traits, anxiety and their association with signs and symptoms of temporomandibular disorders in the adolescents. Afri Health Sci. 2019;19(1). 1801 1810. https:// dx.doi. org/10.4314/ ahs. v19i1.57

58. Kosar C, Besen DB. Adaptation of a patient activation measure (PAM) into Turkish: reliability and validity test. Afri Health Sci. 2019;19(1). 1811-1820. https:// dx.doi. org/10.4314/ ahs. v19i1.58 